\title{
Identification and validation of uterine stimulant methylergometrine as a potential inhibitor of caspase-1 activation
}

\author{
Guillermo García-Laínez $^{1} \cdot$ Mónica Sancho $^{1}$ - Vanessa García-Bayarri ${ }^{1}$ • \\ Mar Orzáez ${ }^{1}$ (1)
}

Published online: 28 July 2017

(c) The Author(s) 2017. This article is an open access publication

\begin{abstract}
Inflammasomes are intracellular multiprotein complexes of the innate immune system. Upon an inflammatory insult, such as infection or intracellular damage, a nucleotide-binding oligomerization domain-like receptor (NLR) sensor protein and the adaptor protein ASC (apoptosis-associated speck-like protein containing a caspase activation and recruitment domain) are assembled to activate protease procaspase-1. This protease processes pro-IL-1 $\beta$ and pro-IL-18 cytokines, which are released to induce the inflammatory response. De-regulation of inflammasome contributes to the progression of several diseases, such as Alzheimer's disease, diabetes, cancer, inflammatory and autoimmune disorders. We herein describe the identification of methylergometrine (MEM), a drug currently used as a smooth muscle constrictor during postpartum hemorrhage, as an inhibitor of the inflammasome complex in ASC-mediated procaspase-1 activation screening. MEM inhibits the activation of the nucleotide-binding oligomerization domain-like receptor protein 1 (NLRP1) and nucleotide-binding oligomerization domain-like receptor protein 3 (NLRP3) inflammasomes in cellular models upon different
\end{abstract}

Guillermo García-Laínez and Mónica Sancho equally contributed to the work.

Electronic supplementary material The online version of this article (doi:10.1007/s10495-017-1405-z) contains supplementary material, which is available to authorized users.

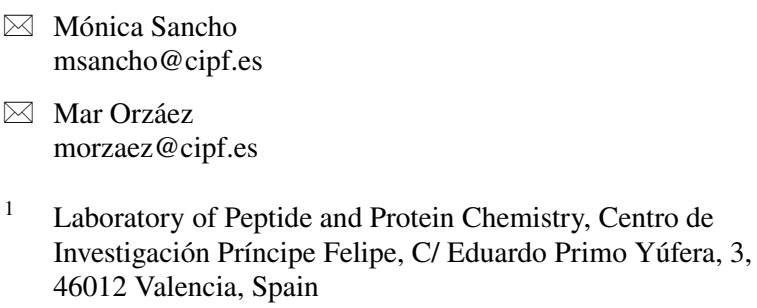

pro-inflammatory stimuli. Our results suggest that MEM has the potential to reposition in the treatment of inflammatory diseases with the advantages of established safety and clinical data.

Keywords Caspase-1 inhibitor · Ergometrine · Inflammasome inhibitor · Inflammation .

Methylergometrine

\section{Introduction}

Inflammation is a protective response of the body to ensure removal of detrimental stimuli and repair damaged tissue [1]. Cells of the innate immune system, such as macrophages and dendritic cells, recognize the conserved microbial structures called pathogen-associated molecular patterns (PAMPs) and danger-associated molecular patterns (DAMPs) [2]. At least four major pattern recognition receptor (PRR) families operate cooperatively to detect invading microbes or endogenous danger signals: Toll-like receptors, RIG-I-like receptors, C-type lectin receptors, and nucleotide-binding oligomerization domain leucine-rich repeat containing receptors (NLRs) [3, 4]. After microbial recognition, PRRs induce the activation of different signaling pathways that result in the synthesis of pro-inflammatory cytokines such as interleukin (IL)- $1 \beta$ (IL-1 $\beta$ ) and IL-18 [5]. IL-1 $\beta$ and IL-18 are synthesized as precursor molecules, which can be cleaved into their mature and active forms by caspase- 1 protease. This activation occurs when the cell receives a second signal (PAMP or DAMP) to activate NLRs and promotes the assembly of a large multiprotein complex called the inflammasome. Inflammasomes are a group of multimeric protein complexes formed by the NLR sensor protein, the adaptor protein 
ASC (the apoptosis-associated speck-like protein containing a caspase activation and recruitment domain (CARD)) and protease procaspase-1 (PC1). ASC interacts through the pyrin domain with sensors, and through the CARD with PC1. The formation of this complex leads to the proximity-induced activation of PC1 [6]. Once activated, caspase-1 hydrolyses the inactive forms of pro-inflammatory cytokines IL-1 $\beta$ and IL-18 (pro-IL-1 $\beta$ and pro-IL-18) by triggering their secretion and initiating the inflammation process. The most reported consequence of caspase- 1 activation is the rapid secretion of cytokines, but caspase-1 activation in macrophages also leads to caspase-1-dependent cell death called pyroptosis [7-9].

Abnormal inflammasome activation has been implicated in the pathophysiology of Alzheimer's disease [10, 11], diabetes [12] and cancer [13, 14], and also leads to many inflammatory and autoimmune diseases, including gout, silicosis, rheumatoid arthritis and genetically-inherited periodic fever syndromes [15-18].

The identification of small molecule inhibitors that target the inflammasome is an important step in developing effective therapeutics to treat inflammation. Recently developed treatments for inflammasome-related diseases target processes downstream of PC1 activation. These include Anakinra, a recombinant IL-1 receptor antagonist [19, 20], Canakinumab, a neutralizing IL-1 $\beta$ antibody [21, 22], and Rilonacept, a soluble decoy IL-1 receptor [23]. Several relevant strategies have also identified new drugs that target different intervention points in the cascade of inflammasome activation, such as MCC950 [24], Glyburide [25], $\beta$-hydroxybutyrate [26] and VX-765 [27].

In this study, we address the identification of new modulators of the inflammasome by targeting ASC-mediated PC1 activation and employing a drug repurposing strategy. The major advantage of drug repurposing is that it saves the time and cost for drug development, and permits the rapid inclusion of the molecule in clinical trials [28, 29]. We describe the identification of methylergometrine (MEM), a synthetic analog of ergonovine prescribed for treating postpartum hemorrhage, as an inhibitor of ASC-mediated PC1 activation and demonstrate the inflammasome inhibition activity of this drug in cellular models of inflammation.

\section{Results}

\section{Identification of modulators of the ASC-mediated activation of PC1}

Identification of inflammasome inhibitors was accomplished by targeting the specific interaction of $\mathrm{PC} 1$ with the adaptor molecule ASC. The Prestwick Chemical Library ${ }^{\circledR}$ composed of 880 FDA-approved drugs, selected for their chemical and pharmacological diversity and safety in humans, was evaluated in a caspase- 1 activity fluorescence assay. Recombinant PC1 and ASC were combined to obtain a functional complex. Once reconstituted, self-cleavage produces PC1 activation. Active caspase-1 hydrolyzes substrate Ac-WEDH-AFC by releasing the fluorogenic AFC molecule (Fig. 1a). Compounds were pre-incubated with recombinant ASC to facilitate the selection of the molecules that affect the ASC/PC1 interaction interface. A $60 \%$ inhibition threshold was applied, and those compounds that showed intrinsic fluorescence or color were ruled out. Three compounds were initially selected as inhibitors of ASC-mediated PC1 activation: ursolic acid, MEM and sulfasalazine. A secondary screening was performed to confirm positive hits and to rule out direct inhibitors of active caspase-1 (Fig. 1a). Ursolic acid and MEM were selected as inhibitors of the ASC-mediated activation of caspase-1 (Fig. 1b).

In order to confirm ursolic acid and MEM as positive hits, the dose-response effect on the ASC-dependent PC1 activation assay was analyzed. In the presence of ursolic acid and MEM, activity was inhibited in a dose-response manner with an $\mathrm{IC}_{50}$ value (compound concentration that provides 50\% inhibition of activity) within the low micromolar range (15.5 and $16.3 \mu \mathrm{M}$, respectively) (Fig. 2a, b). Both compounds were then evaluated in a cellular environment for toxicity. For this purpose, we employed THP-1 cells, a human monocyte-derived cell line frequently used as a mammalian cellular model for inflammasome activation studies. Ursolic acid was ruled out because of the high toxicity observed in THP-1 cells (Fig. 2c). However, MEM showed a non toxic profile at the range of concentrations from 1 to $50 \mu \mathrm{M}$ (Fig. 2d).

\section{Anti-inflammatory capacity of MEM as an inhibitor of the ASC-mediated activation of PC1}

To investigate the anti-inflammatory properties of MEM, its activity was assayed in THP-1 cells upon different proinflammatory signaling. NLRP1 and NLRP3 are ASCdependent inflammasomes [30], and thus appropriate cellular targets to evaluate identified inhibitors. The NLRP1 inflammasome was activated by using a combination of lipopolysaccharide (LPS) and muramyldipeptide (MDP) stimuli [31]. Then NLRP1 inhibition was evaluated at three different MEM concentrations. IL-1 $\beta$ and IL-18 secretion, cytotoxicity and PC1 activation were analyzed in all cases (Fig. 3). VX-765, a pro-drug that is undergoing clinical research which inhibits caspase- 1 and reduces the release of IL- $1 \beta$ and IL-18, was used as a positive control of caspase-1 inhibition [27]. A significant inhibition of IL-1 $\beta$ and IL-18 release were detected at $100 \mu \mathrm{M}$ of MEM (Fig. 3a, b). In order to confirm these results obtained in the ELISA 


\section{a}

Primary screening

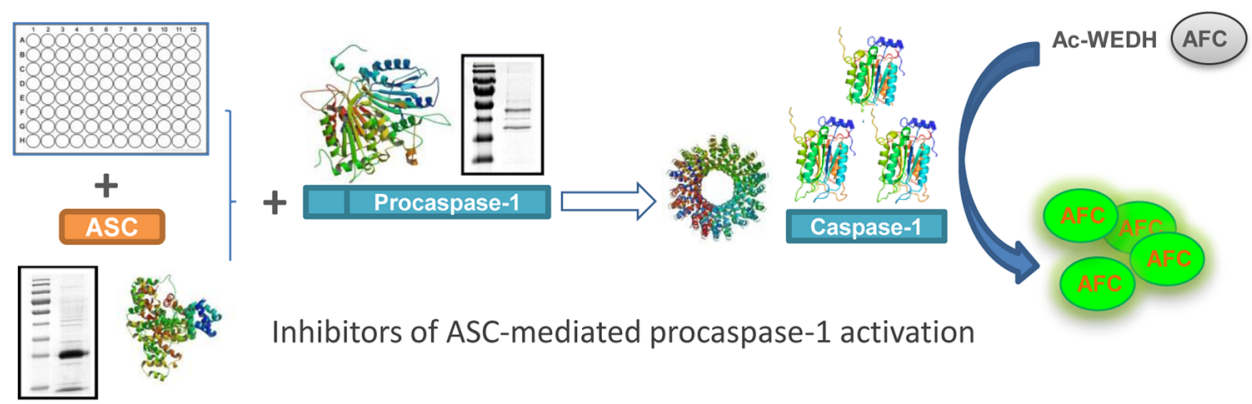

Secondary assay

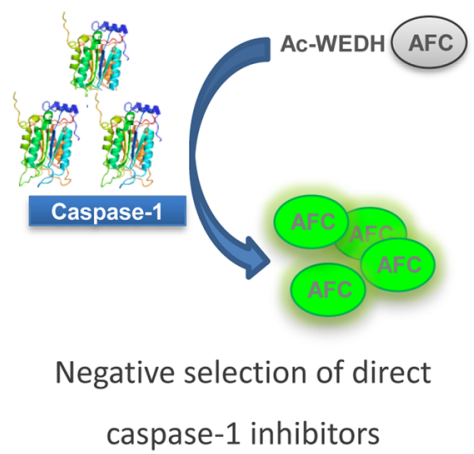

Fig. 1 Identification of the modulators of the ASC-mediated activation of PC1. a Scheme of the 96-well plate assays performed to identify inhibitors. Primary screening: ASC-dependent PC1 activation was monitored in vitro by the release of AFC from fluorogenic PC1 substrate Ac-WEHD-AFC in the presence of 880 FDA-approved compounds $(20 \mu \mathrm{M})$ from the Prestwick Chemical Library. Secondary screening: caspase-1 activation was monitored in vitro by the release of AFC from fluorogenic PC1 substrate Ac-WEHD-AFC in

assays, immunoblotting of cellular supernatants was also performed. A significant inhibition of caspase- 1 and IL- $1 \beta$ cleavage was observed at the highest MEM dose (Fig. 3c and Supp Data 1). The observed drop in proIL-1 $\beta$ in the MEM-treated samples could be a consequence of IL-1 $\beta$ cleavage inhibition. The active form of this cytokine acts as a positive autocrine signal to induce a feedback loop of proIL-1 $\beta$ expression [32].

Inflammasome activation also produces pyroptosis and, consequently, the release of lactate dehydrogenase (LDH) to media. However, VX-765, the inhibitor of caspase-1, does not affect pyroptosis in THP-1 cells. Interestingly, MEM treatment reduces the release of LDH. Thus MEM is able to partially inhibit pyroptosis produced by inflammasome activation (Fig. 3d).

In order to activate the NLRP3 inflammasome, a combination of LPS and adenosine triphosphate (ATP) stimuli was used [31]. Inhibition of IL-1 $\beta$ and IL-18 secretion by MEM gave similar results as in the case of NLRP1 (Fig. 4a, b). Immunoblotting experiments showed that proIL- $1 \beta$ b

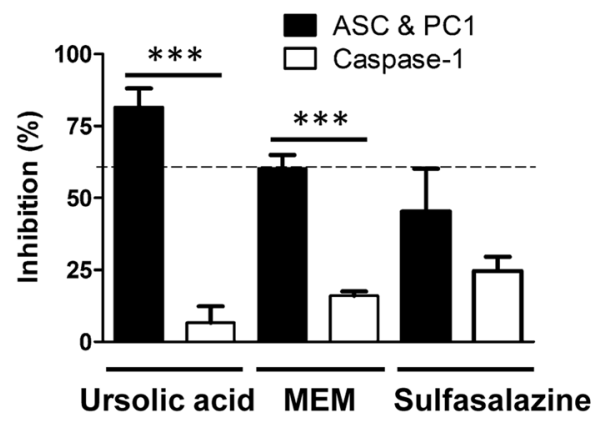

the presence of the positive hits $(20 \mu \mathrm{M})$ obtained in the previous assay. b Graphical representation of the behavior of the three selected compounds in the primary (black bars) and secondary screening (white bars) at $20 \mu \mathrm{M}$ in DMSO. A Student's $t$-test statistical analysis $(* * * p<0.01)$ was performed to compare the caspase-1 inhibition for each compound in the presence or absence of ASC. Data represent the mean $\pm \mathrm{SD}$ of three experiments

decreased at the highest MEM concentration [32], as well as diminished caspase- 1 and IL-1 $\beta$ processing (Fig. 4c and Supp data 1). The analysis of cellular pyroptosis by the release of LDH to media showed similar results to the NLRP1 inflammasome activation study. A lower cytotoxicity was observed in the MEM-treated cells than in the VX765-treated cells (Fig. 4d), which indicates that MEM protects cells from pyroptotic damage.

\section{Discussion}

MEM (or methergine) is a synthetic analog of ergonovine, a psychedelic alkaloid found in ergot. It is a smooth muscle constrictor that functions via the antagonism of the dopamine D1 receptor which mostly acts on the uterus [33, 34]. To this end, it is widely used in obstetrics to prevent or control excessive bleeding following childbirth and abortion. This study shows that MEM also exerts an inhibitory effect on PC1 activation, a key protein in the inflammation 

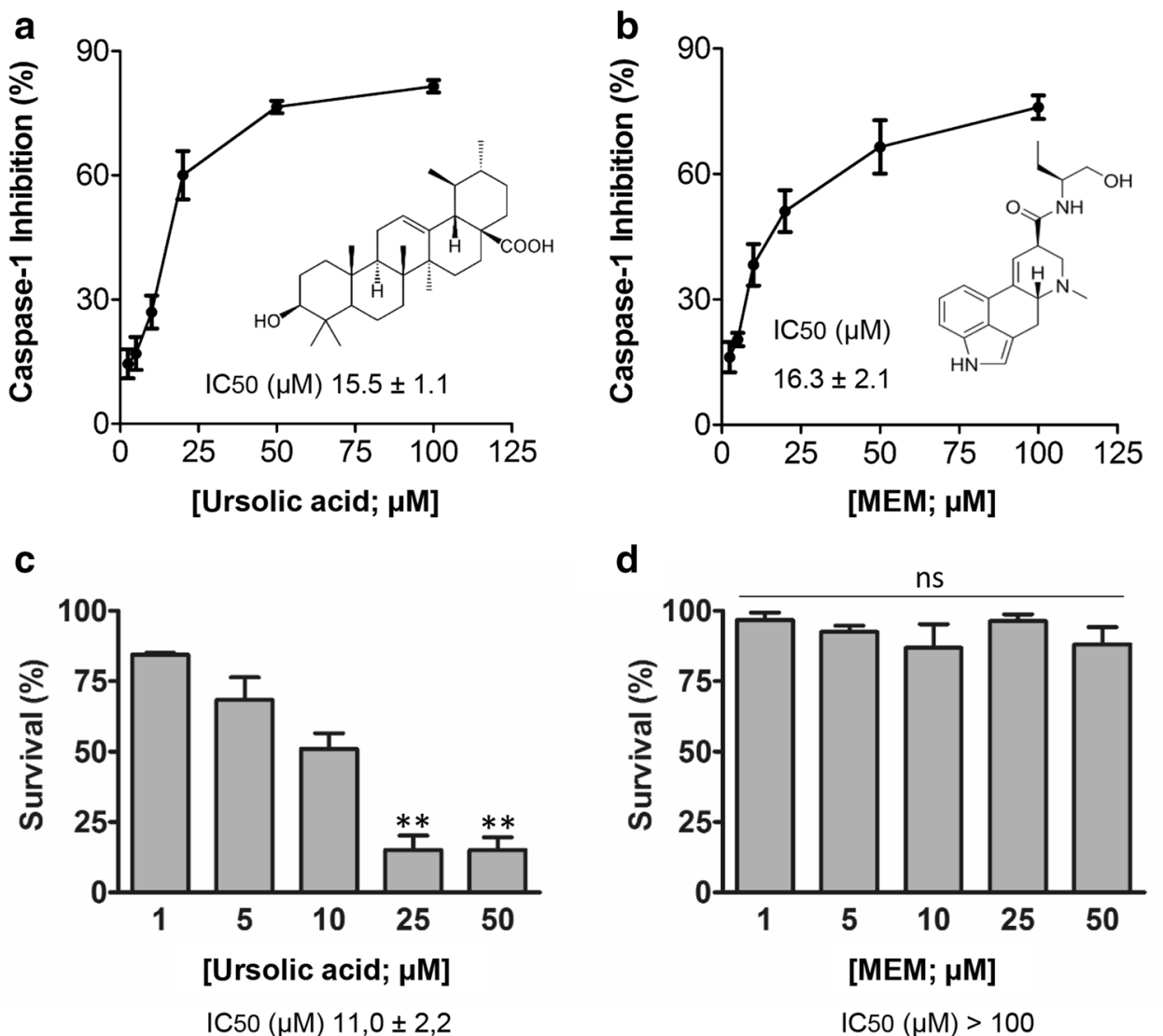

Fig. 2 The activity and toxicity profiles of ursolic acid and MEM. Dose-response activity of ursolic acid (a) and MEM (b) in vitro. The inhibitory effect of both compounds on ASC-dependent PC1 activation was followed by incubating PC1 and ASC with different concentrations of each compound: ursolic acid $(2.5,5,10,20,50$ and $100 \mu \mathrm{M})$ and $\operatorname{MEM}(2.5,5,10,20,50$ and $100 \mu \mathrm{M})$. Data are reported as the percentage of inhibition compared with the untreated sample. The concentration that provided $50 \%$ inhibition of the complex $\left(\mathrm{IC}_{50}\right)$ was calculated. Data represent the mean $\pm \mathrm{SD}$ of three

experiments. Toxicity was evaluated in THP-1 cells. The cell viability measured by the MTS assay was monitored after $24 \mathrm{~h}$ of treatment with the indicated concentrations of both compounds, ursolic acid (c) and MEM (d). Data are reported as the percentage of live cells compared with the untreated sample. Data represent the mean \pm SD of three experiments. Asterisks represent significant differences, as determined by a one-way ANOVA test with Dunnetts's multiple post test comparison $* * \mathrm{p}<0.05$, ns means non significant

process, in vitro and cell-based assays with an $\mathrm{IC}_{50}$ within the micromolar range. Similar results were obtained in both the NLRP1 and NLRP3 inflammasome activation models.

It is noteworthy that MEM is also able to significantly reduce the release of LDH caused by inflammasome activation in THP-1 cells. Compound VX-765 is the most effective inhibitor of caspase-1 as it acts on the catalytic site of the enzyme [27], but does not decrease pyroptosis in THP-1 cells. MEM is able to inhibit pyroptosis and enhance cell recovery. This result supports the hypothesis that targeting ASC-mediated PC1 activation is an advantage for cell protection over active caspase-1 inhibition. In line with our data, recent research has given rise to the development of a single domain antibody fragment that specifically recognizes the CARD domain of human ASC [35]. This antibody impairs ASC (CARD) interactions, inhibits inflammasome activation and, more importantly,

protects cells from inflammatory cell death. Our results reinforce the idea that the perturbation of ASC interaction interfaces could be a potential target for the development of broad-spectrum anti-inflammatory agents with improved cell recovery capabilities.

MEM is the first pass metabolite of the methysergide maleate drug [36]. The anti-inflammatory activity of methysergide maleate has been reported in systemic burn edema, asthma and endotoxemia animal models, but the mechanism of action has not been thoroughly explored [37-39]. In these models, the contribution of the inflammasome has been recently reported [40, 41]. Although further research will be required to clarify the in vivo anti-inflammatory activity of MEM, our results suggest the contribution of inflammasome inhibition to the antiinflammatory effects observed in asthma and endotoxemia models. 

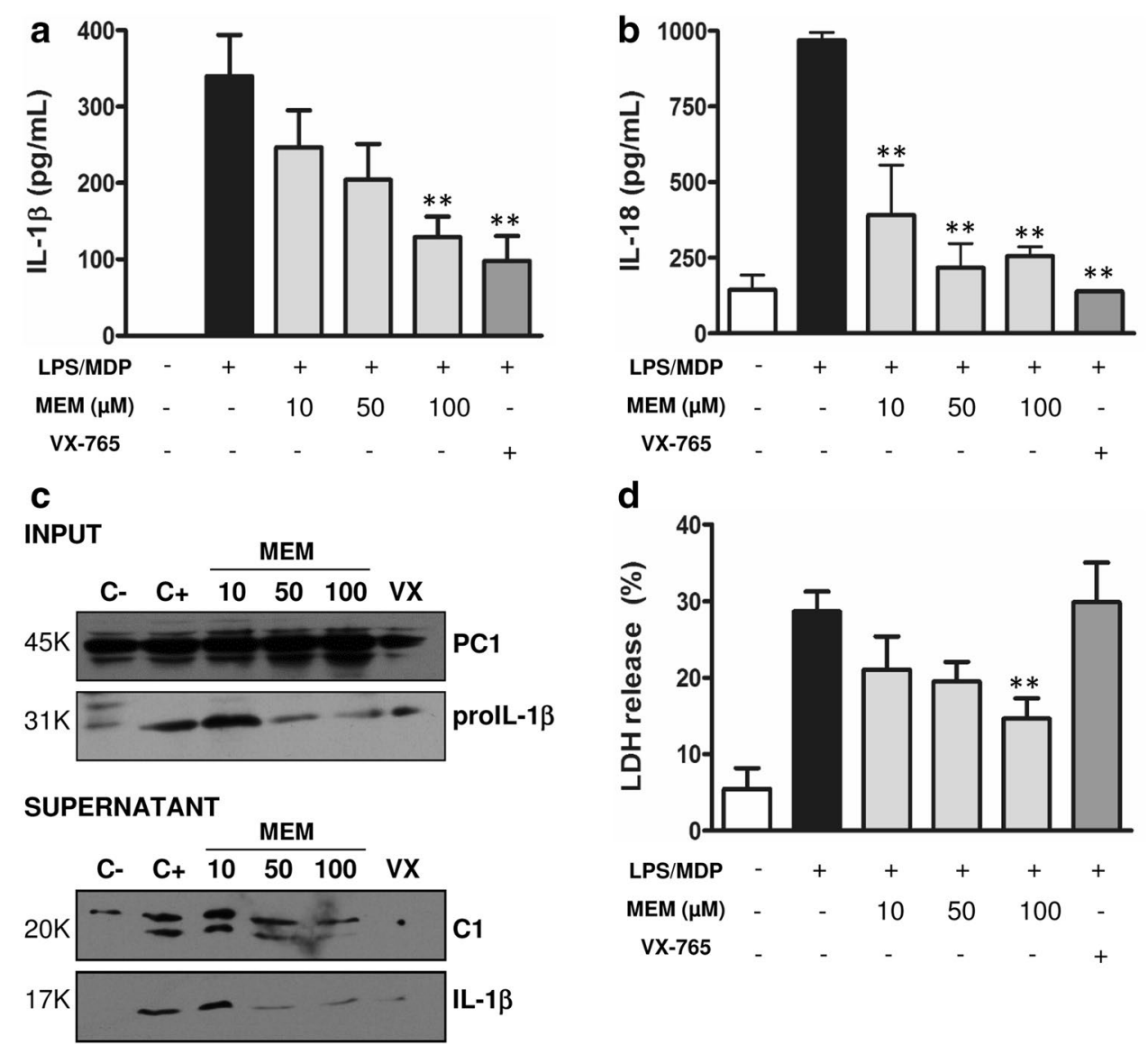

Fig. 3 MEM inhibits the NLRP1-dependent inflammasome in THP-1 cells. IL-1 $\beta$ (a) and IL-18 (b) secretion was evaluated by the ELISA technique upon activation of the NLRP3 inflammasome with LPS $(100 \mathrm{ng} / \mathrm{ml})$ and MDP $(50 \mu \mathrm{g} / \mathrm{ml})$. Cells were treated with MEM at 10,50 or $100 \mu \mathrm{M}$, and with VX-765 (VX) at $5 \mu \mathrm{M}$. c THP-1 cells were stimulated as described above, and supernatants and inputs were analyzed by Western blotting; IL- $1 \beta$ and cleaved caspase-1 (C1) were detected. The shown data are representative of three inde-

\section{Materials and methods}

\section{Purification of procaspase-1 (PC1)}

Human His-tagged PC1 was previously cloned in the pFastBac vector for Baculovirus expression. The expression plasmid was transformed into DH10Bac Escherichia coli cells. Recombinant bacmids were purified and used to transfect Sf9 insect cells. The virus stock was amplified and used to infect suspension cultures. Briefly, Sf9 cells were grown in $2 \mathrm{~L}$ of Grace's Insect Medium (Gibco) and infected at 1,500,000 cells $/ \mathrm{mL}$ with a recombinant virus that contained His-tagged PC1 at a multiplicity of infection of 1 (MOI 1). Then they were cultured for $16 \mathrm{~h}$ at $27{ }^{\circ} \mathrm{C}$ with constant gentle agitation to express the protein. Cells were centrifuged at $1000 \mathrm{~g}$ for $10 \mathrm{~min}$ at $4{ }^{\circ} \mathrm{C}$ and washed with PBS. The pellet was lysed with buffer lysis $(100 \mathrm{mM}$

pendent experiments. d Measurement of the release of LDH into the extracellular medium under the above-described conditions. C-: cells non-treated and $\mathrm{C}+$ : cells treated with stimuli activation but without the anti-inflammatory treatment. Asterisks represent significant differences to the positive control $(\mathrm{C}+)$, as determined by a one-way ANOVA test with Dunnetts's multiple post test comparison $* * \mathrm{p}<0.05$. All the data are expressed as the mean \pm SD of three experiments

Hepes-KOH, pH 7.5, $50 \mathrm{mM} \mathrm{KCl,} 7.5 \mathrm{mM} \mathrm{MgCl} 2,5 \mathrm{mM}$ NaEDTA, 5 mM NaEGTA and proteases inhibitors: Pepstatin, Leupeptin and PMSF) using a Douncer and clarified by centrifugation $\left(10,000 \mathrm{~g}, 1 \mathrm{~h}\right.$ at $\left.4{ }^{\circ} \mathrm{C}\right)$. The resulting supernatant that contained the recombinant protein was purified in an Ni-NTA (Ni2p-nitrilotriacetate)-agarose column. After elution, $\mathrm{PC} 1$ was further purified by ion exchange chromatography (Mono Q) in $20 \mathrm{mM}$ of Hepes- $\mathrm{KOH}, \mathrm{pH}$ 7.5, $10 \mathrm{mM} \mathrm{KCl}, 1.5 \mathrm{mM} \mathrm{MgCl} 2,1 \mathrm{mM}$ EDTA, $1 \mathrm{mM}$ EGTA.

\section{Purification of the apoptosis-associated speck-like pro- tein (ASC)}

Human ASC was previously cloned in the peT28a vector for its expression in E. coli cells. Briefly, $8 \mathrm{~L}$ of LB medium, plus antibiotics chloramphenicol and kanamycin, 

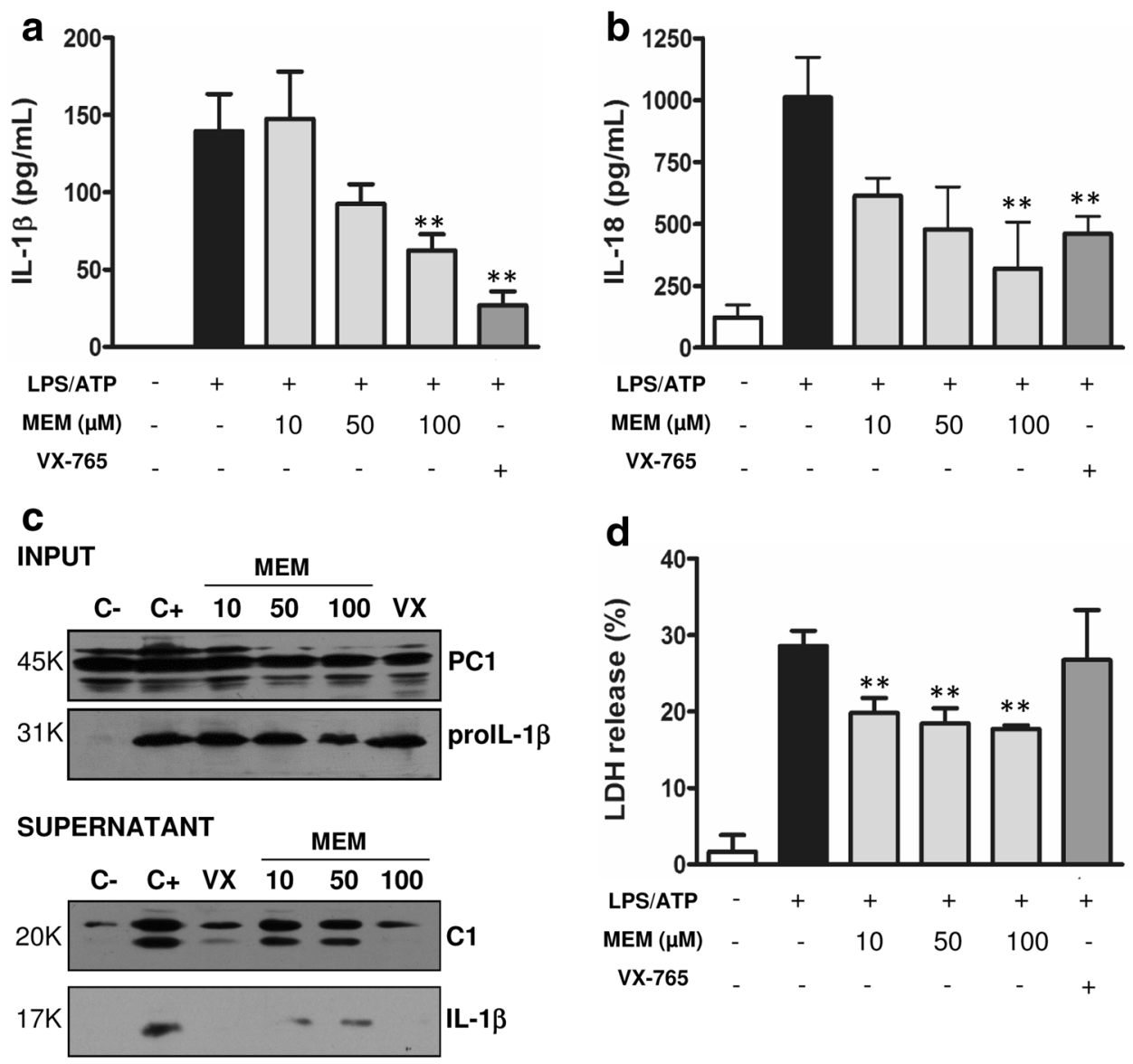

Fig. 4 MEM inhibits the NLRP3-dependent inflammasome in THP-1 cells. IL-1 $\beta$ (a) and IL-18 (b) secretion was evaluated by the ELISA technique upon activation of the NLRP3 inflammasome with LPS $(100 \mathrm{ng} / \mathrm{ml})$ and ATP $(2.5 \mathrm{mM})$. Cells were treated with MEM at 10,50 or $100 \mu \mathrm{M}$, and with VX-765 (VX) at $5 \mu \mathrm{M}$. c THP-1 cells were stimulated as described above, and supernatants and inputs were analyzed by Western blotting; IL- $1 \beta$ and cleaved caspase- 1 (C1) were detected. The shown data are representative of three inde-

were inoculated with an overnight culture of freshly transformed His tagged-ASC-pet28a-BL21 (DE3) pLys E. coli cells (Invitrogen), and grown at $37{ }^{\circ} \mathrm{C}$ until OD 0.7. The ASC expression was induced with $0.7 \mathrm{mM}$ IPTG at $28^{\circ} \mathrm{C}$ for $4 \mathrm{~h}$. Cells were harvested $\left(15 \mathrm{~min}, 6000 \mathrm{rpm}\right.$ at $\left.4{ }^{\circ} \mathrm{C}\right)$, lysed in $300 \mathrm{~mL}$ of Buffer A $\left(50 \mathrm{mM} \mathrm{NaH} \mathrm{PO}_{4}, 300 \mathrm{mM}\right.$ $\mathrm{NaCl}, \mathrm{pH}$ 8.0) and sonicated. After centrifugation at $11,000 \mathrm{rpm}$ for $1 \mathrm{~h}$ at $4{ }^{\circ} \mathrm{C}$, ASC was present in the inclusion bodies (pellet). Pellets were then resuspended in 100 $\mathrm{mL}$ of denaturing Buffer $\mathrm{B}\left(50 \mathrm{mM} \mathrm{NaH} \mathrm{PO}_{4}, 300 \mathrm{mM}\right.$ $\mathrm{NaCl}, 8 \mathrm{M}$ urea, $\mathrm{pH} 8.0$ ) and resonicated. Under these conditions, the His tagged-ASC protein was solubilized and purified using TALON resin (Qiagen). Re-folding was performed in the TALON resin at a gradient of decreasing urea concentrations and the protein was finally eluted in $15 \mathrm{~mL}$ of Buffer $\mathrm{C}\left(50 \mathrm{mM} \mathrm{NaH} \mathrm{N}_{2} \mathrm{PO} 4,300 \mathrm{mM} \mathrm{NaCl}\right.$, $500 \mathrm{mM}$ imidazol, $\mathrm{pH}$ 8.0). Desalting was performed in a

pendent experiments. d Measurement of the release of LDH into the extracellular medium under the above-described conditions. $\mathrm{C}-$ : cells non-treated and $\mathrm{C}+$ : cells treated with stimuli activation but without the anti-inflammatory treatment. Asterisks represent significant differences to the positive control $(\mathrm{C}+)$, as determined by a one-way ANOVA test with Dunnetts's multiple post test comparison $* * \mathrm{p}<0.05$. All the data are expressed as the mean \pm SD of three experiments

PD-10 column and the protein was finally concentrated in a 10K Amicon concentrator unit.

\section{Primary screening: the ASC-mediated PC1 reconstitu- tion in vitro assay}

Recombinant PC1 $(75 \mathrm{nM})$ was pre-incubated with the indicated concentrations of compounds for $20 \mathrm{~min}$ at RT in Assay Buffer (20 mM Hepes pH 7.5, $10 \mathrm{mM} \mathrm{KCl,} 1.5 \mathrm{mM}$ $\mathrm{MgCl}_{2}, 1 \mathrm{mM}$ EDTA, $1 \mathrm{mM}$ EGTA, $1 \mathrm{mM}$ DTT). Then $300 \mathrm{nM}$ of ASC were added and incubated for another 10-min period. Caspase-1 activation was measured using fluorogenic substrate Ac-WEHD-AFC ( $80 \mu \mathrm{M}$; PeptaNova) by continuously monitoring the release of the AFC product in a Wallac Victor 1420 workstation. The Prestwick Chemical Library ${ }^{\circledR}$ is composed of 880 FDA-approved drugs dissolved in DMSO. The compounds were initially 
tested at $20 \mu \mathrm{M}$ with $1 \%$ of DMSO. Data are reported as the percentage of inhibition compared with the absence of the compound.

\section{Secondary screening: the caspase- 1 in vitro activation assay}

Recombinant caspase-1 $(75 \mathrm{nM})$ was incubated with the indicated concentrations of compounds for $20 \mathrm{~min}$ at RT in Assay Buffer. Then fluorogenic substrate Ac-WEHDAFC $(80 \mu \mathrm{M})$ was added and activity was monitored in a Wallac Victor 1420 workstation. Data are reported as the percentage of inhibition compared with the absence of the inhibitor.

\section{Toxicity assay: the MTS (3-(4,5-dimethylthia-} zol-2-yl)-5-(3-carboxymethoxyphenyl)-2-(4-sulfophenyl)-2H-tetrazolium, inner salt) assay

THP- 1 is a cell line that is derived from human acute monocytic leukemia purchased from ATCC. THP-1 cells were cultured in RPMI supplemented with $10 \%$ FBS (Sigma) at $37^{\circ} \mathrm{C}$ and $5 \% \mathrm{CO}_{2}$.

Cell proliferation was measured with the CellTiter $96^{\circledR}$ Aqueous Non-Radioactive Cell Proliferation Assay kit (Promega) according to the manufacturer's instructions. THP-1 cells were plated in 96-well plates at a cellular density of 10,000 cells/well. Cells were treated with the indicated compounds at five concentrations for $24 \mathrm{~h}$. Plates were read at $490 \mathrm{~nm}$ by a Wallac Victor 1420 workstation.

\section{The inflammasome activation cellular assays}

The molecules were evaluated in the THP- 1 cells stimulated with LPS and MDP, or with LPS plus ATP, to stimulate ASC-dependent inflammasomes NLRP1 and NLRP3, respectively. Briefly, $1 \times 10^{6}$ cells were seeded in 6 -well plates in $1 \mathrm{~mL}$ RPMI media that contained $1 \%$ FBS. Cells were either mock-treated or primed with compounds at the indicated concentrations for $30 \mathrm{~min}$, followed by treatment with $100 \mathrm{ng} / \mathrm{mL}$ LPS (Sigma) and $50 \mu \mathrm{g} / \mathrm{mL}$ MDP (Sigma) or $2.5 \mathrm{mM}$ ATP (Sigma) for $6 \mathrm{~h}$ at $37{ }^{\circ} \mathrm{C}$. Supernatants were harvested and clarified by centrifugation at $1500 \mathrm{rpm}$ at RT and a cytokine analysis was performed.

Both IL- $1 \beta$ secretion and the release of IL- 18 were monitored by an ELISA assay (BD OptEIA ${ }^{\mathrm{TM}}$ Human IL- $1 \beta$ ELISA Kit and Human IL-18 Module Set eBioscience) following the manufacturer's instructions. Cell viability was analyzed in parallel by evaluating the release of $\mathrm{LDH}$ according to a commercial kit (CytoTox-ONE ${ }^{\mathrm{TM}}$ Homogeneous Membrane Integrity Assay; Promega). The release of LDH was calculated using the formula: release of LDH $(\%)=100 \times($ Abs490 treated - Abs490 untreated cells $) /$
Abs490 untreated cells lysed with Triton 9\% (maximum release of $\mathrm{LDH})$.

\section{Immunoblotting}

The supernatants of the treated cells were precipitated by the chloroform-methanol method, as described by De Nardo and Latz [42]. Pellets were obtained by lysing cells in $25 \mathrm{mM}$ of Tris-HCl, pH 7.4, 1 mM EDTA, 1 mM EGTA and $1 \%$ SDS, plus protease and phosphatase inhibitors. The protein concentration was determined by the BCA protein assay. Samples were separated in a $14 \%$ SDS-PAGE gel, transferred to a nitrocellulose membrane and blocked with 5\% skimmed milk for $1 \mathrm{~h}$. Then the membrane was incubated overnight with primary antibodies: $\alpha$-casp1 (1:1000; Cell Signaling \#2225) and $\alpha$-IL-1 $\beta$ (1:1000; Acris \#R1130P) at $4{ }^{\circ} \mathrm{C}$. Membranes were washed and probed with the appropriate secondary antibody conjugated with peroxidase for enhanced chemiluminescence detection (Amersham Pharmacia Biotech).

\section{Statistical analysis}

Data were analyzed with the GraphPad software and statistical significance was assessed by a Student's $t$-test or a oneway analysis of variance (ANOVA) test with Dunnetts's multiple post test comparison (**p $<0.05 ; * * * \mathrm{p}<0.01)$.

Acknowledgements This paper is dedicated to the memory of Enrique Pérez-Payá. We thank all the members of our laboratory for discussion. This work was supported by grants from the Spanish Ministry of Economy and Competitiveness (Grant BFU2016-79487 and SAF2014-52614-R), and the Generalitat Valenciana (Prometeo 2014/061 and GV/2016/197). García-Laínez was funded by a predoctoral fellowship from JAE-pre CSIC from the Spanish government (JaePre021).

\section{Compliance with ethical standards}

Conflict of interest The authors declare that they have no conflict of interest.

Open Access This article is distributed under the terms of the Creative Commons Attribution 4.0 International License (http:// creativecommons.org/licenses/by/4.0/), which permits unrestricted use, distribution, and reproduction in any medium, provided you give appropriate credit to the original author(s) and the source, provide a link to the Creative Commons license, and indicate if changes were made.

\section{References}

1. Medzhitov R (2008) Origin and physiological roles of inflammation. Nature 454(7203):428-435. doi:10.1038/nature07201 
2. Akira S, Uematsu S, Takeuchi O (2006) Pathogen recognition and innate immunity. Cell 124(4):783-801. doi:10.1016/j. cell.2006.02.015

3. Bauernfeind F, Ablasser A, Bartok E, Kim S, Schmid-Burgk J, Cavlar T, Hornung V (2010) Inflammasomes: current understanding and open questions. Cell Mol Life Sci 68(5):765-783. doi:10.1007/s00018-010-0567-4

4. Ting JP, Lovering RC, Alnemri ES, Bertin J, Boss JM, Davis BK, Flavell RA, Girardin SE, Godzik A, Harton JA, Hoffman HM, Hugot JP, Inohara N, Mackenzie A, Maltais LJ, Nunez G, Ogura Y, Otten LA, Philpott D, Reed JC, Reith W, Schreiber S, Steimle V, Ward PA (2008) The NLR gene family: a standard nomenclature. Immunity 28(3):285-287. doi:10.1016/j. immuni.2008.02.005

5. Takeuchi O, Akira S (2010) Pattern recognition receptors and inflammation. Cell 140(6):805-820. doi:10.1016/j. cell.2010.01.022

6. Lu A, Magupalli VG, Ruan J, Yin Q, Atianand MK, Vos MR, Schroder GF, Fitzgerald KA, Wu H, Egelman EH (2014) Unified polymerization mechanism for the assembly of ASC-dependent inflammasomes. Cell 156(6):1193-1206. doi:10.1016/j. cell.2014.02.008

7. Bergsbaken T, Fink SL, Cookson BT (2009) Pyroptosis: host cell death and inflammation. Nat Rev Microbiol 7(2):99-109. doi:10.1038/nrmicro2070

8. Miao EA, Leaf IA, Treuting PM, Mao DP, Dors M, Sarkar A, Warren SE, Wewers MD, Aderem A (2010) Caspase-1-induced pyroptosis is an innate immune effector mechanism against intracellular bacteria. Nat Immunol 11(12):1136-1142. doi:10.1038/ ni. 1960

9. Sollberger G, Strittmatter GE, Garstkiewicz M, Sand J, Beer HD (2014) Caspase-1: the inflammasome and beyond. Innate immun 20(2):115-125. doi:10.1177/1753425913484374

10. Halle A, Hornung V, Petzold GC, Stewart CR, Monks BG, Reinheckel T, Fitzgerald KA, Latz E, Moore KJ, Golenbock DT (2008) The NALP3 inflammasome is involved in the innate immune response to amyloid-beta. Nat Immunol 9(8):857-865. doi:10.1038/ni.1636

11. Olsen I, Singhrao SK (2016) Inflammasome involvement in Alzheimer's disease. J Alzheimer's Dis 54(1):45-53. doi:10.3233/ JAD-160197

12. Masters SL, Dunne A, Subramanian SL, Hull RL, Tannahill GM, Sharp FA, Becker C, Franchi L, Yoshihara E, Chen Z, Mullooly N, Mielke LA, Harris J, Coll RC, Mills KH, Mok KH, Newsholme P, Nunez G, Yodoi J, Kahn SE, Lavelle EC, O’Neill LA (2010) Activation of the NLRP3 inflammasome by islet amyloid polypeptide provides a mechanism for enhanced IL-1beta in type 2 diabetes. Nat Immunol 11(10):897-904. doi:10.1038/ni.1935

13. Ghiringhelli F, Apetoh L, Tesniere A, Aymeric L, Ma Y, Ortiz C, Vermaelen K, Panaretakis T, Mignot G, Ullrich E, Perfettini JL, Schlemmer F, Tasdemir E, Uhl M, Genin P, Civas A, Ryffel B, Kanellopoulos J, Tschopp J, Andre F, Lidereau R, McLaughlin NM, Haynes NM, Smyth MJ, Kroemer G, Zitvogel L (2009) Activation of the NLRP3 inflammasome in dendritic cells induces IL-1beta-dependent adaptive immunity against tumors. Nat Med 15(10):1170-1178. doi:10.1038/nm.2028

14. Guo B, Fu S, Zhang J, Liu B, Li Z (2016) Targeting inflammasome/IL-1 pathways for cancer immunotherapy. Scientific reports 6:36107. doi:10.1038/srep36107

15. Heymann MC, Rosen-Wolff A (2013) Contribution of the inflammasomes to autoinflammatory diseases and recent mouse models as research tools. Clin Immunol 147(3):175-184. doi:10.1016/j. clim.2013.01.006

16. Cassel SL, Eisenbarth SC, Iyer SS, Sadler JJ, Colegio OR, Tephly LA, Carter AB, Rothman PB, Flavell RA, Sutterwala FS (2008) The Nalp3 inflammasome is essential for the development of silicosis. Proc Natl Acad Sci USA 105(26):9035-9040. doi:10.1073/pnas.0803933105

17. Masters SL (2013) Specific inflammasomes in complex diseases. Clin Immunol 147(3):223-228. doi:10.1016/j.clim.2012.12.006

18. Moll M, Kuemmerle-Deschner JB (2013) Inflammasome and cytokine blocking strategies in autoinflammatory disorders. Clin Immunol 147(3):242-275. doi:10.1016/j.clim.2013.04.008

19. Granowitz EV, Porat R, Mier JW, Pribble JP, Stiles DM, Bloedow DC, Catalano MA, Wolff SM, Dinarello CA (1992) Pharmacokinetics, safety and immunomodulatory effects of human recombinant interleukin-1 receptor antagonist in healthy humans. Cytokine 4(5):353-360

20. Wakabayashi G, Gelfand JA, Burke JF, Thompson RC, Dinarello CA (1991) A specific receptor antagonist for interleukin 1 prevents Escherichia coli-induced shock in rabbits. FASEB J 5(3):338-343

21. Dinarello CA, van der Meer JW (2013) Treating inflammation by blocking interleukin-1 in humans. Semin Immunol 25(6):469484. doi:10.1016/j.smim.2013.10.008

22. Rondeau JM, Ramage P, Zurini M, Gram H (2015) The molecular mode of action and species specificity of canakinumab, a human monoclonal antibody neutralizing IL-1beta. MAbs 7(6):1151-1160. doi:10.1080/19420862.2015.1081323

23. Hoffman Hal M. YUaKP (2008) Rilonacept. Nat Rev Drug Discov 7:385-386. doi:10.1038/nrd2579

24. Coll RC, Robertson AA, Chae JJ, Higgins SC, Munoz-Planillo R, Inserra MC, Vetter I, Dungan LS, Monks BG, Stutz A, Croker DE, Butler MS, Haneklaus M, Sutton CE, Nunez G, Latz E, Kastner DL, Mills KH, Masters SL, Schroder K, Cooper MA, O'Neill LA (2015) A small-molecule inhibitor of the NLRP3 inflammasome for the treatment of inflammatory diseases. Nat Med 21(3):248-255. doi:10.1038/nm.3806

25. Lamkanfi M, Mueller JL, Vitari AC, Misaghi S, Fedorova A, Deshayes K, Lee WP, Hoffman HM, Dixit VM (2009) Glyburide inhibits the Cryopyrin/Nalp3 inflammasome. J Cell Biol 187(1):61-70. doi:10.1083/jcb.200903124

26. Youm YH, Nguyen KY, Grant RW, Goldberg EL, Bodogai M, Kim D, D'Agostino D, Planavsky N, Lupfer C, Kanneganti TD, Kang S, Horvath TL, Fahmy TM, Crawford PA, Biragyn A, Alnemri E, Dixit VD (2015) The ketone metabolite betahydroxybutyrate blocks NLRP3 inflammasome-mediated inflammatory disease. Nat Med 21(3):263-269. doi:10.1038/nm.3804

27. Stack JH, Beaumont K, Larsen PD, Straley KS, Henkel GW, Randle JC, Hoffman HM (2005) IL-converting enzyme/caspase-1 inhibitor VX-765 blocks the hypersensitive response to an inflammatory stimulus in monocytes from familial cold autoinflammatory syndrome patients. J Immunol 175(4):2630-2634

28. Padhy BM, Gupta YK (2011) Drug repositioning: re-investigating existing drugs for new therapeutic indications. J Postgrad Med 57(2):153-160 doi:10.4103/0022-3859.81870

29. Sekhon B (2013) Repositioning drugs and biologics:Retargeting old/existing drugs for potential new therapeutic applications. J Pharm Educ Res 4:1

30. Franchi L, Eigenbrod T, Munoz-Planillo R, Nunez G (2009) The inflammasome: a caspase-1-activation platform that regulates immune responses and disease pathogenesis. Nat Immunol 10(3):241-247. doi:10.1038/ni.1703

31. Gregory SM, Davis BK, West JA, Taxman DJ, Matsuzawa S, Reed JC, Ting JP, Damania B (2011) Discovery of a viral NLR homolog that inhibits the inflammasome. Science 331(6015):330-334. doi:10.1126/science.1199478

32. Toda Y, Tsukada J, Misago M, Kominato Y, Auron PE, Tanaka Y (2002) Autocrine induction of the human pro-IL-1beta gene promoter by IL-1beta in monocytes. J Immunol 168(4):1984-1991

33. Berde B (1978) Pharmacology of ergot alkaloids in clinical use. Med J Aust 2(3 Suppl):3-13 
34. Pertz HH, Milhahn H, Eich E (1999) Cycloalkanecarboxylic esters derived from lysergol, dihydrolysergol-I, and elymoclavine as partial agonists and antagonists at rat 5-HT2A receptors: pharmacological evidence that the indolo[4,3-fg]quinoline system of the ergolines is responsible for high 5-HT2A receptor affinity. $\mathrm{J}$ Med Chem 42(4):659-668. doi:10.1021/jm981092u

35. Schmidt FI, Lu A, Chen JW, Ruan J, Tang C, Wu H, Ploegh HL (2016) A single domain antibody fragment that recognizes the adaptor ASC defines the role of ASC domains in inflammasome assembly. J Exp Med 213(5):771-790. doi:10.1084/ jem. 20151790

36. Bredberg U, Eyjolfsdottir GS, Paalzow L, Tfelt-Hansen P, TfeltHansen V (1986) Pharmacokinetics of methysergide and its metabolite methylergometrine in man. Eur J Clin Pharmacol 30(1):75-77

37. Hernekamp JF, Hu S, Schmidt K, Walther A, Lehnhardt M, Kremer T (2013) Methysergide attenuates systemic burn edema in rats. Microvasc Res 89:115-121. doi:10.1016/j.mvr.2013.03.002

38. Lima C, Souza VM, Soares AL, Macedo MS, Tavares-deLima W, Vargaftig BB (2007) Interference of methysergide, a specific 5-hydroxytryptamine receptor antagonist, with airway chronic allergic inflammation and remodelling in a murine model of asthma. Clinical Exp Allergy 37(5):723-734. doi:10.1111/j.1365-2222.2007.02700.x

39. Walther A, Yilmaz N, Schmidt W, Bach A, Gebhard MM, Martin E, Schmidt H (2001) Methysergide attenuates leukocyte-independent plasma extravasation during endotoxemia. J Crit Care 16(3):121-126. doi:10.1053/jcrc.2001.28975

40. Besnard AG, Guillou N, Tschopp J, Erard F, Couillin I, Iwakura Y, Quesniaux V, Ryffel B, Togbe D (2011) NLRP3 inflammasome is required in murine asthma in the absence of aluminum adjuvant. Allergy 66(8):1047-1057. doi:10.1111/j.1398-9995.2011.02586.x

41. Kim SR, Kim DI, Kim SH, Lee H, Lee KS, Cho SH, Lee YC (2014) NLRP3 inflammasome activation by mitochondrial ROS in bronchial epithelial cells is required for allergic inflammation. Cell Death Dis 5:e1498. doi:10.1038/cddis.2014.460

42. De Nardo CM, Latz E (2013) The inflammasome. Biology MiM. Springer, New York 